University-Community Engagement and

Public Relations Education: A

Replication and Extension of Service-

Learning Assessment in the Public

Relations Campaigns Course

\author{
Betty Farmer \\ Lane Graves Perry, III \\ Inhyuck "Steve" Ha
}

This article was originally published at:

https://journals.sfu.ca/iarslce/index.php/journal/article/view/244/172

Recommended Citation

Farmer, B., Perry, L. G. III, \& Ha, I. (2016). University-community engagement and public relations education: A replication and extension of service-learning assessment in the public relations campaigns course. International Journal of Research on Service-Learning and Community Engagement, 4(1), 235-254. 


\title{
University-Community Engagement and Public Relations Education: A Replication and Extension of Service-Learning Assessment in the Public Relations Campaigns Course
}

\author{
Betty Farmer \\ Lane Graves Perry, III \\ Inhyuck "Steve" Ha \\ Western Carolina University
}

\begin{abstract}
This study replicated and extended Werder and Strand's 2011 research by framing service-learning within the larger context of a university's overall community engagement strategy and by including alumni within the survey population. The findings supported a general service-learning assessment instrument measuring students' perceptions of their development of key public relations skills, along with citizenship and social responsibility mindsets, as a result of their participation in community-based projects in a public relations capstone course. While the results, overall, were consistent with Werder and Strand's study, there were notable differences. For example, this study found that there were no statistically significant difference in means - by gender, time, and client type - for most variables. However, alumni who had worked for businesses in a town designated as an official community engagement partner had higher mean scores on three items: community involvement, strategic planning skills, and ability to work with others. The findings contribute to the collective understanding of community engagement, public relations education and practice, and the lasting impact of service-learning on students post-graduation. Whether servicelearning values such as citizenship and social responsibility "stick" after graduation is a key consideration for any profession, but especially for public relations.
\end{abstract}

Keywords: public relations, service-learning, community engagement, citizenship, student outcomes

This study replicated Werder and Strand's (2011) research, which found support for a general servicelearning assessment instrument that measures students' perceptions of their development of key public relations skills, along with citizenship and social responsibility mindsets, as a result of their participation in community-based projects in a Public Relations (PR) Campaigns course. This study also extended Werder and Strand's work by framing service-learning in a PR Campaigns class within the larger context of a university's overall community engagement strategy. Specifically, it explored the extent to which PR students believed their work with real-world clients helped the university achieve its mission as an "engaged" institution and whether they thought the PR Campaigns course should be structured to assist students' development in citizenship and social responsibility. To further probe dimensions of citizenship and social responsibility, the study revised Werder and Strand's instrument to include items from the Community Service Involvement Preference Inventory (CSIPI) (Payne, 2000) that focus primarily on how students' perceptions of service are influenced by their service experience. The CSIPI seeks to identify shifts from exploratory approaches to service (whereby volunteers are apprehensive, self-serving, or short-term regarding their service commitment) to assimilatory approaches (whereby volunteers are committed to frequent engagement, focused on a clear cause, and tend to make lifelong career/lifestyle decisions based on "responsible citizenship").

This study also sought to answer Slater, Bartoo, and Puglisi's (2011) question related to best practices in PR Campaigns course pedagogy: "Do graduates retain comprehension of the significance PR practitioners play in the life of a community and their social responsibility toward the community?" (p. 120). Since previous research has suggested that lapse of time is an important factor in students' 
perceptions of their development of civic-mindedness and social responsibility, this study diverged from Werder and Strand's (2011) approach by surveying alumni. Consequently, the results of this study contribute to the understanding of the lasting impacts of service-learning on alumni, an area ripe for additional research across disciplines.

\section{Overview of a PR Campaigns Course}

The population for this study comprised students who had graduated within the previous five years from an undergraduate public relations program at a university in the southeastern United States. This university has held the Carnegie Foundation for the Advancement of Teaching's elective Community Engagement Classification since 2008. Actively embracing the pedagogy of service-learning, PR students at this engaged university develop and implement a communication project for an actual client over the course of a semester. Both the value of service-learning and the challenges and benefits of using real clients in advanced PR courses have been well documented (e.g., Aldoory \& Wrigley, 2000; Allison, 2008; Farmer, 1997; Gleason \& Vilette 2012; Kinnick, 1999; Sallot, 1996; Slater et al., 2011; Texter \& Smith, 1999). The vast majority of the student PR campaigns at the authors' university fall within the "project plan implementation approach," which requires students to propose, execute, and evaluate a PR project (Texter \& Smith, 1999, p. 169). The benefits of the implementation approach include working in teams, meeting deadlines, evaluating the degree to which proposed strategies and tactics actually help achieve objectives, developing portfolio-quality materials, and developing relationships with clients and community members. Arguably, the implementation approach is as close to the "real world" as education gets.

Aldoory and Wrigley (2000) maintained, however, that one of the most compelling reasons for students to work with real clients is that it helps them place classroom materials into meaningful contexts. As Gleason and Violette (2012) wrote:

There is no better way for students to experience the rigorous academic dimensions of Public Relations concepts and theory than through the real world application of this knowledge, as well as by contributing to the good of external organizations while advancing their own professional skills. (p. 284)

Emphasizing the value of service-learning to external audiences, Kinnick (1999) encouraged faculty and students to look beyond the students' own professional development toward the impact of their work on the community. Similarly, Daugherty (2003) asserted that service-learning can "help students enrich their appreciation and understanding of the interests of stakeholders and the importance of social responsibility - key concepts in public relations education" (p. 2). Daugherty further surmised that service-learning in the PR curriculum "appears to be an ideal method to train students to become adept in the skills needed for the workplace and to shape their value system so they will perform their work in a socially responsible way" (p. 5).

The faculty teaching the PR Campaigns course at the engaged university where this study took place are mindful of and embrace these larger responsibilities and opportunities associated with service-learning. In addition to being required to develop a portfolio of professional materials from their campaigns, students are also asked to write a two- to three-page reflection paper answering the following questions: (1) What have you learned about public relations as a result of being in this course?; (2) What have you learned about yourself during this course, including your personal purpose and values?; (3) What have you learned about working with others, including your peers, your professor, and your client?; and (4) What have you learned about community engagement, social responsibility, and/or citizenship?

Since the inception of the PR Campaigns course in 1993, students have implemented a wide variety of campaigns for both non- and for-profit organizations. From 2009 to 2015, PR students had the opportunity to help businesses in a small neighboring tourist town, which had become the focus of a 
special university-wide engagement initiative. In 2009, community leaders in the town had approached the university's chancellor for assistance. Local merchants had experienced a major loss in revenue due to the departure of the town's main tourist attraction, a scenic railway, as well as to the nationwide economic downturn in 2008. Several businesses in this tourism-dependent town had shut their doors, and many of those that remained were struggling. Citing the university's "moral obligation" to help the town, which is located less than 15 minutes from the main campus, the chancellor announced a university-wide initiative to use the expertise and resources of the university to address the town's challenges and opportunities. This resulting five-year partnership involved dozens of faculty and staff and hundreds of students across numerous disciplines.

From spring 2010 to spring 2015, at least one group of students in the university's senior-level PR Campaigns class, taught by two different communication faculty members, was assigned to the small tourist town per semester. During this time period, the learning objectives and course assignments (e.g., to develop and implement a public relations project for a real-world client) remained the same. However, the nonprofit clients changed every year, and while the small-town client also stayed the same, the type of projects completed for it varied greatly, ranging from training merchants in the use of social media, to promoting a mobile web application for the town created by the university's computer information systems students, to promoting special events like the annual festival of lights and luminaries. Some of these campaigns produced measureable results. For example, as a result of the PR students' promotion of the 2012 "Lights \& Luminaries" festival, merchants reported that their sales doubled from previous years. After the 2013 festival, the town's mayor concluded that the work faculty and students completed as part of the PR Campaigns course "has led this festival to unprecedented growth, resulting in several merchants reporting December 6, 2013 as their most successful day since the economic downturn." These results were especially important because for many small businesses a strong holiday sales season can mean the difference between staying open and closing.

The partnership between the university and the small town has clearly represented a mutually beneficial relationship. The luminaries and mobile website campaigns have also received awards for excellence in community engagement from a national communication association, and the university has received positive publicity as a result of this community relations initiative-a tangible example of its community engagement mission in action. Additionally, graduates have reported that their involvement in these real-world campaigns helped them to secure jobs. For instance, two students who helped produce an electronic newsletter for the town both secured jobs immediately after graduation, and both were told by their employers that their work on the e-newsletter were important factors in their hiring decisions.

However, additional assessment around the benefits of the service-learning component of the PR Campaigns class to students is needed. Since spring 2010, approximately half of the students enrolled in the university's PR Campaigns class have been assigned to the small tourist town. Since this client was both for-profit and designated as an official university focus, would the students working with this partner have different assessments and perceived outcomes than the students working for nonprofits or campusbased clients? Would the fact that students were working for a client identified as an ongoing and formal university engagement partner impact their service-learning experience? Would the students perceive themselves as helping the university achieve its community engagement mission, regardless of their client focus?

According to Campus Compact (2013) - a nationally recognized arbiter of community engagementone key indicator of university-community engagement is whether "all members of the campus community demonstrate their familiarity with and ownership of the institution's mission." The authors of this study, however, are not aware of any research that evaluates students' awareness of the connection between their university's mission, their formal, designated community partners, and their servicelearning activities. Kinnick (1999) advised that faculty should prepare students for community-based learning by stressing that the students are representatives of the university and that their work reflects back on the institution. Since one of the primary roles of PR professionals is to help organizations fulfill their missions, it is important to explore whether PR students are making this connection. 


\section{Review of the Literature}

\section{University Engagement and PR: Mutually Beneficial Relationships, Partnerships, and Reciprocity}

Numerous articles have lauded the benefits of university-community engagement, and considerable research has documented those benefits for both the communities with which universities partner and the educational institutions themselves. As a result of their public engagement initiatives, universities may improve their relationships and reputation with communities (Driscoll, Holland, Gelmon, \& Kerrigan, 1996; Gray, Ondaatje, Fricker, \& Geschwind, 2000). Buys and Bursnall (2007) held that universitycommunity partnerships can "enhance university profile and status through ... raised profile[s] of faculties, schools and research centres" (p. 82). Indeed, the mutually beneficial nature of university public engagement echoes the mutually beneficial ideals and values of the practice of public relations.

The Carnegie Foundation (2013) defines community engagement as the

collaboration between institutions of higher education and their larger communities (local, regional/state, national, global) for the mutually beneficial exchange of knowledge and resources in a context of partnership and reciprocity. The purpose of community engagement is the partnership of college and university knowledge and resources with those of the public and private sectors to enrich scholarship, research, and creative activity; enhance curriculum, teaching and learning; prepare educated, engaged citizens; strengthen democratic values and civic responsibility; address critical societal issues; and contribute to the public good.

Universities benefit from public engagement in many ways, including public recognition and public relations opportunities. Distinctions such as the Carnegie Foundation's elective Community Engagement Classification represent important elements of a university's overall branding and marketing efforts. Many universities intentionally craft their public image around their engagement profile; university PR professionals frame the story of their institution's engagement successes in admissions materials, on the institution's website, in news releases, and through a variety of internal channels (Driscoll, 2008).

\section{Service-Learning and Community-Engaged Pedagogy}

One of the integral components of any community engagement project is an operationalized pedagogy (e.g., service-learning, community-based research, public service internships, etc.) (Holland, 1997). Stanton's (2009) review of community engagement literature noted more than 165 different published definitions of the term service-learning. Despite these myriad definitions, they do share a commonly accepted set of characteristics and elements, including a contextual balance of community-valued service engagement and relevant in-class curriculum with an intentional and clear focus on the integral role of reflection on the learner's experience (Eyler \& Giles, 1999). Stanton (2009) offered a similar conceptualization: "Service-learning is about the joining of two complicated concepts - community action, the 'service', and efforts to learn from that action and connect what is learned to existing knowledge, testing it, and confirming [or challenging] it along the way" (p. 45). While the balance may differ on a case-by-case basis, in order for the approach to be referred to as service-learning, it will possess these characteristics (Stanton, 2009).

\section{The Effects of Service-Learning on Students}

What are the characteristics of service-learning pedagogy that so robustly influence the commonly accepted outcomes related to students' personal growth (e.g., attitudes toward self), academic enhancement (e.g., attitudes toward disciplines and learning), and civic engagement (Celio, Durlak, \& Dymnicki, 2011; Clayton et al., 2005)? When Eyler and Giles (1999) asked "Where's the learning in service-learning?" they concluded that the "learning in service-learning is in the questions. It is in the 
questions that service situations inherently pose, in the guided reflection provided by skilled teachers and facilitators and by the interplay of existing knowledge with new and dissonant experiences" (p. 207). The experience whereby a student is charged to utilize, apply, and test course content to meet an identified community need provides the learner with an opportunity to reflect iteratively on real-life experience and to question assumptions.

Citing a significant body of literature, Eyler, Giles, Stenson, and Gray (2001) and Celio, Durlak, and Dymnicki (2011) concluded that service-learning positively effects interpersonal development and the ability to work with others; leadership and communication skills; a sense of social responsibility; and the development of citizenship skills. While these particular outcomes have been well-researched, essentially serving as "ends" or "end results," this study explored the "means," or more specifically the approach to service-learning used, and investigated the longer-term implications and presence of these outcomes for students post-graduation.

Eyler et al.'s (2001) annotated review of nearly a decade's worth of service-learning research highlighted findings across several broad categories, including personal outcomes, social outcomes, learning outcomes, career development, institutional relationships with the community, citizenship development, diversity, and self and identity (among others). Table 1 organizes key service-learning studies (mostly within the discipline of communication) into the three broad categories in which most of the literature on the effects of service-learning falls, according to Roldan, Strage, and David (2004): civic engagement, personal growth, and academic enhancement.

Table 1. Review of Service-Learning Studies Investigating Impact on Select Outcomes

\begin{tabular}{|c|c|c|c|}
\hline $\begin{array}{l}\text { Author, Sample, } \\
\text { Method, and } \\
\text { Course }\end{array}$ & Civic Engagement & Personal Growth & Academic Enhancement \\
\hline $\begin{array}{l}\text { Werder \& Strand } \\
(2011) \\
\mathrm{n}=210 \\
\text { ANOVA tests, linear } \\
\text { regression analysis } \\
\text { Public Relations } \\
\text { Campaigns }\end{array}$ & $\begin{array}{r}\text { Students' perceived } \\
\text { proficiency in citizenship } \\
\text { through developing abilities } \\
\text { to make a difference in the } \\
\text { community and recognizing } \\
\text { social responsibility }\end{array}$ & $\begin{array}{r}\text { Students' perceived ability } \\
\text { to assume personal } \\
\text { responsibility, } \\
\text { development of caring } \\
\text { relationships, and } \\
\text { sensitivity to others }\end{array}$ & $\begin{array}{r}\text { Students' perceived } \\
\text { understanding of public } \\
\text { relations interpersonal and } \\
\text { practical skills including } \\
\text { application of knowledge and } \\
\text { communication skills }\end{array}$ \\
\hline $\begin{array}{l}\text { Celio, Durlak, \& } \\
\text { Dymnicki (2011) } \\
\mathrm{n}=11,837 \\
\text { Meta-analysis design } \\
\text { Mixed Disciplines }\end{array}$ & $\begin{array}{r}\text { Civic engagement, social } \\
\text { skills }\end{array}$ & $\begin{array}{r}\text { Attitudes toward self, } \\
\text { social skills }\end{array}$ & $\begin{array}{r}\text { Attitudes toward school and } \\
\text { learning, academic } \\
\text { achievement }\end{array}$ \\
\hline $\begin{array}{l}\text { Witmer, Silverman, \& } \\
\text { Gaschen (2009) } \\
\mathrm{n}=127 \\
\text { Mixed-methods } \\
\text { design } \\
\text { Public Relations }\end{array}$ & $\begin{array}{r}\text { Application to real-world } \\
\text { settings, teamwork, civic } \\
\text { responsibility }\end{array}$ & $\begin{array}{r}\text { Teamwork, growth of } \\
\text { public relations } \\
\text { practitioners, interactions } \\
\text { with PR clients }\end{array}$ & $\begin{array}{l}\text { Development of skills as } \\
\text { public relations practitioners }\end{array}$ \\
\hline $\begin{array}{l}\text { Blomstrom \& Tam } \\
(2008) \\
\mathrm{n}=32 \\
\text { Qualitative thematic } \\
\text { analysis of reflections } \\
\text { Public Relations }\end{array}$ & N/A & $\begin{array}{l}\text { Self-awareness/self- } \\
\text { discovery was the most } \\
\text { frequently described } \\
\text { response and discovered } \\
\text { strengths, creative side, } \\
\text { and sensitivity to others, } \\
\text { gained confidence }\end{array}$ & $\begin{array}{r}\text { Learned how to work in a } \\
\text { group setting, learned how to } \\
\text { make themselves heard, how } \\
\text { to align member strengths, } \\
\text { and how to contribute to a } \\
\text { team, learned about audience } \\
\text { analysis, understanding } \\
\text { client's environments, } \\
\text { adaptability and how to take } \\
\text { criticism }\end{array}$ \\
\hline
\end{tabular}




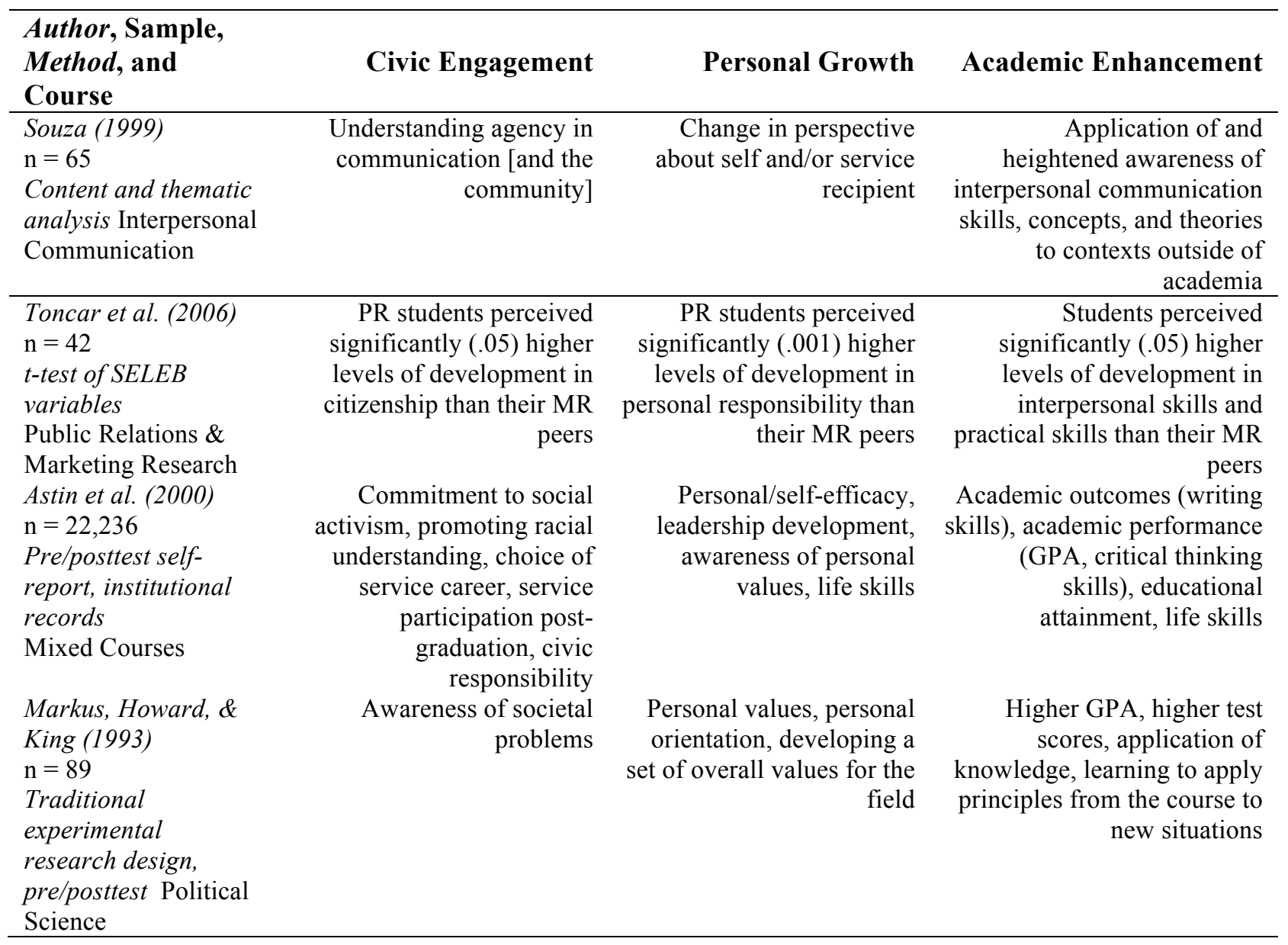

Previous research has established correlations between volunteer service in college and involvement in community service post-graduation (e.g., Astin, Sax, \& Avalos, 1999; Smedick, 1996). According to Fenzel and Peyrot (2005), both general community service and service-learning experiences as undergraduates positively predicted alumni's attitudes toward personal and social responsibilities, their involvement in community service post-graduation, and their attitudes toward service-related careers. Significant results were limited to those courses in which service was an integral component and in which there were more hours of service and more reflection activity. Given that the PR Campaigns course under study met all three of these criteria, there was reason to believe that this study of PR alumni would yield similar findings.

Finally, Weber and Weber (2010) found that students reported a larger impact on civic attitudes further away from the service-learning experience. This could suggest that the true measure of servicelearning may need to come after students have graduated and moved on in their respective career, family, and civic life. (p. 91) This aligns with the idea that learning, even with the adoption of reflection efforts, is gradual. This study makes an important contribution to the literature by exploring the impact of servicelearning and the development of citizenship and social responsibility mindsets on PR alumni.

\section{Methodology}

To replicate Werder and Strand (2011), this study tested the following hypotheses:

- H1: Student perceptions of general service-learning (GSL) benefits will be high (mean $>5$ on a 
7-point scale) in the PR course.

- H2: Student perceptions of GSL benefits will predict perceived effectiveness of the PR course.

- H3: Student perceptions of discipline-specific learning (DSL) benefits will be high (mean $>5$ on a 7-point scale) in the PR course.

- H4: Student perceptions of DSL benefits will predict perceived effectiveness of the PR course.

The study also replicated Werder and Strand's research questions:

- RQ1: What learning benefits are the best predictors of perceived course effectiveness?

- RQ2: Are there differences in student perceptions of experiential learning outcomes due to gender or client type?

This study also extended Werder and Strand's (2011) research by exploring the following questions:

- RQ3: What impact, if any, does time have on students' perceptions of volunteerism, social responsibility, and citizenship?

- RQ4: Do students assigned to an official university partner (in this case, a small tourist town) report different perceptions/experiences for any of the variables?

- RQ5: To what extent do PR students working on real-world projects in the community perceive their work as helping the university achieve its mission as an engaged university?

- RQ6: Do graduates believe that universities generally and the PR course specifically should foster future students' development in citizenship and social responsibility?

- RQ7: Do graduates retain comprehension of the significance that PR practitioners play in the life of a community and their social responsibility toward that community?

\section{The Survey Instrument: Informing Quantitative and Qualitative Data Collection}

For this study, Werder and Strand (2011) granted permission to use their instrument, and Payne (1992) granted permission to use the Community Service Involvement Preference Inventory. Werder and Strand's instrument was used almost in its entirety, with only a few minor deletions and revisions. In the "General Service-Learning Experiences" section, item 5, "Understanding cultural and racial differences," was edited to just "Understanding cultural differences." The authors felt that culture was more appropriate for this study in that it served as an umbrella term. In the "PR Learning Experiences" section, the authors added a category for technology/social media skills since we believed such skills are increasingly important to students' professional development. The "Team Position" category was eliminated because the authors' university does not assign positions but, rather, expects students to participate fully during each step of the campaign process - although clearly some students assume leadership roles in one area or another. Finally, participants in this study were asked to specify the client for which they worked.

Additional items were informed by the CSIPI and aligned with the assimilatory preference of service involvement, which reflects a lifestyle and career decision to align an individual's purpose with the community as a way of enacting responsible citizenship. This is more than doing service when a person has time, and more about aligning career and lifestyle aspirations with service (Payne, 2000):

- "I believe involvement in community service will have a positive impact on my quality of life."

- "I have made career decisions based on my community engagement experience."

- "I feel a lifelong commitment to helping others."

- "I often think about how my involvement will impact those I serve."

- "Involvement in community service has influenced the way I live my life." 
- "I volunteer to show future employers my interest in the community."

Two additional questions were added:

- "I believe I have a greater understanding of the problems that impact our communities."

- "I believe I can have a positive impact on issues in my community."

All of these latter items focused primarily on students' perceptions of how their engagement experience informed their approach to service.

In order to answer RQ5, three questions were created to assess whether graduates believed their work in the PR course helped the university achieve its mission in three specific areas: improving individual lives in the region, enhancing economic development, and enhancing community development.

To answer RQ6, two questions were posed: (1) "In your opinion should universities play a role in the development of students' civic mindedness?" (respondents could answer "Yes" or "No," with a prompt for further explanation); (2) "In your opinion, should the PR Campaigns class be structured to support students' development in citizenship and social responsibility?" (respondents could answer "Yes" or "No," with a prompt for further explanation).

The online survey was generated using Qualtrics software. The population chosen for the survey included students who had completed the PR Campaigns class during a five-year period from the spring semester of 2009 to the spring semester of 2013). All students had completed the course during their senior year. An examination of the class lists for the selected years revealed that two students had withdrawn from (and therefore had not completed) the course. This left a total of 122 possible survey respondents. The authors, university support staff, and student workers undertook the task of identifying current email addresses for those individuals; for the period designated for the study, 53 current email addresses were secured.

The online survey was administered to the 53 graduates over a 10-day period in October 2013. A letter encouraging participation accompanied the survey. To increase the response rate, as many as two reminder emails were sent to those who did not respond. The survey closed with 37 responses, representative a response rate of $69.8 \%$. Because one response was missing a considerable amount of information, 36 responses were used for analysis. The respondents ranged in age from 21 to 40 years, with an average age of 25 . Thirty-seven percent of respondents were male, and $63 \%$ were female.

\section{Data Analysis: Quantitative and Qualitative Approaches}

Quantitative data were analyzed using IBM SPSS Statistics 20. To test the hypotheses, the dimensionality was assessed using factor analysis. The items were combined to create composite measures. To test $\mathrm{H} 1$ and $\mathrm{H} 3$, means were examined. For H2, H4, and RQ1, linear regression analyses were used. Mean difference tests were conducted to inform RQ2, RQ3, and RQ4.

Qualitative data, collected primarily from open-ended prompts within the survey, were analyzed by the researchers individually, and then emergent themes were discussed to determine dependability and confirmability of both the shared themes and those that did not align across the analyses. The researchers' goal in processing the qualitative data for interpretation was "to reconstruct the categories used to conceptualize experiences and world view" (Lincoln \& Guba, 1985, p. 334) of participants. The primary function of the researchers (i.e., human instruments) was to individually apply inductive data analysis methods with the intention of "uncovering embedded information and making it explicit" (Lincoln \& Guba, 1985, p. 203). Practically, this function was facilitated by unitizing and categorizing the qualitative data. Holsti (1969) explained the coding process as an uncovering of "raw data ... systematically transformed and aggregated into units which permit precise description of relevant content characteristics" (Lincoln \& Guba, 1985, p. 203). In this study, coding was performed through content analysis whereby emergent categories were further discussed in contrast to and in light of the data collected and analyzed. This ultimately led to emergent themes that were coded from the data from respondents. 


\section{Findings}

\section{Quantitative Results}

\section{H1: Student perceptions of GSL benefits will be high (mean $>5$ on a 7-point scale) in the PR course}

To test H1, the means for items to measure GSL were examined. As shown in Table 2, the means ranged from 4.83 to 6.36 . Only one item, "understanding cultural differences," produced a mean below 5 . The item "community involvement" generated the highest mean (6.36) followed by "communication skills" (6.22). The last four columns in Table 2 show the results of factor analysis of items measuring GSL benefits. The principal components analysis (PCA) method was chosen for the initial factor extraction. It is generally accepted that using a rotation in factor analysis produces more interpretable results. The VARIMAX orthogonal rotation method was used in the analysis. Using the factor analysis, means for the composite measures indicated that the respondents perceived that they obtained most experience in communication skills (mean $=6.03)$, followed by application (mean $=5.97)$, personal responsibility $($ mean $=5.92)$, and other orientation (mean $=5.38)$. The findings supported H1.

Table 2. Descriptive Statistics and Principal Component Analysis for General Service-Learning (GSL) Benefits

\begin{tabular}{|c|c|c|c|c|c|c|c|c|}
\hline & \multirow{2}{*}{ Item } & \multirow{2}{*}{ Mean } & \multirow{2}{*}{$\begin{array}{l}\text { Std. } \\
\text { Dev. }\end{array}$} & \multirow{2}{*}{$\begin{array}{r}\text { Factor } \\
\text { Mean }\end{array}$} & \multicolumn{4}{|c|}{ Factor Loading } \\
\hline & & & & & 1 & 2 & 3 & 4 \\
\hline \multirow[t]{6}{*}{$\begin{array}{l}\text { Factor 3: Personal } \\
\text { Responsibility }\end{array}$} & & & & 5.92 & & & & \\
\hline & $\begin{array}{r}\text { Ability to assume } \\
\text { personal } \\
\text { responsibility }\end{array}$ & 6.03 & 1.12 & & & & 0.879 & \\
\hline & $\begin{array}{r}\text { Ability to work with } \\
\text { others }\end{array}$ & 6.06 & 0.83 & & & & 0.731 & \\
\hline & Personal growth & 5.64 & 1.10 & & & & 0.679 & \\
\hline & Organizational skills & 5.89 & 1.17 & & & & 0.621 & \\
\hline & $\begin{array}{l}\text { Problem analysis } \\
\text { and critical thinking }\end{array}$ & 6.00 & 0.86 & & & & 0.516 & \\
\hline \multirow[t]{4}{*}{ Factor 4: Application } & & & & 5.97 & & & & \\
\hline & $\begin{array}{r}\text { Connecting theory } \\
\text { and practice }\end{array}$ & 6.00 & 1.10 & & & & & 0.820 \\
\hline & $\begin{array}{r}\text { Ability to make a } \\
\text { difference in the } \\
\text { community }\end{array}$ & 5.89 & 1.35 & & & & & 0.593 \\
\hline & $\begin{array}{l}\text { Skills in learning } \\
\text { from experience }\end{array}$ & 6.03 & 0.81 & & & & & 0.479 \\
\hline
\end{tabular}

Note. $\mathrm{n}=36$. All items were measured on a 7-point scale. Extraction method: Principal component analysis. Rotation method: Varimax with Kaiser normalization. Blank cells represent loadings $<0.50$. Source: Authors' survey. 


\section{H2. Student perceptions of GSL benefits will predict perceived effectiveness of the PR course}

Model 1 in Table 3 shows the regression results related to the testing of H2. The dependent variable was the overall assessment of effectiveness of the PR Campaigns course, measured on a 7-point scale. The explanatory variables comprised the four composite measures from factor analysis of GSL benefits (see earlier Table 2). The regression results indicated that overall course effectiveness was accounted for by a linear relationship with the four composite measures. Both communication skills and application measures were statistically significant at the $99 \%$ level, while the other two measures - other orientation and personal responsibility-were significant at the $95 \%$ level. The results supported H2.

Table 3. Ordinary Least Square Analysis of Classroom Effectiveness, General Service-Learning (GSL), and Discipline-Specific Learning (DSL) Benefit Factors

\begin{tabular}{|c|c|c|c|c|c|c|}
\hline \multirow[b]{2}{*}{ Variable } & \multicolumn{2}{|c|}{ Model 1} & \multicolumn{2}{|c|}{ Model 2} & \multicolumn{2}{|c|}{ Model 3} \\
\hline & $\begin{array}{r}\text { Coeff. } \\
\text { Est. }\end{array}$ & t stat & $\begin{array}{r}\text { Coeff. } \\
\text { Est. }\end{array}$ & t stat & $\begin{array}{r}\text { Coeff. } \\
\text { Est. }\end{array}$ & t stat \\
\hline Constant & 6.029 & $53.836^{* * *}$ & 6.019 & $56.746^{* * *}$ & 6.022 & $56.357^{* * *}$ \\
\hline Other Orientation (GSL-1) & 0.229 & $2.012^{* *}$ & - & - & 0.157 & 1.212 \\
\hline Communication Skills (GSL-2) & 0.290 & $2.551^{* * *}$ & - & - & 0.144 & 0.989 \\
\hline Personal Responsibility (GSL-3) & 0.212 & $1.870^{* *}$ & - & - & -0.01 & -0.058 \\
\hline Application (GSL-4) & 0.327 & $2.879^{* * *}$ & - & - & 0.154 & 1.104 \\
\hline Organizational Skills (DSL-1) & - & - & 0.346 & $3.125^{* * *}$ & 0.236 & 1.212 \\
\hline Technical Skills (DSL-2) & - & - & 0.415 & $3.908^{* * *}$ & 0.341 & $2.476^{* * *}$ \\
\hline Managerial Skills (DSL-3) & - & - & 0.141 & 1.320 & 0.048 & 0.364 \\
\hline Number of Observations & 35 & & 35 & & 35 & \\
\hline Mean of Dep Variable & 6.029 & & 6.029 & & 6.029 & \\
\hline Adjusted R Squared & 0.350 & & 0.419 & & 0.413 & \\
\hline F value & 5.585 & & 9.176 & & 4.410 & \\
\hline $\operatorname{Pr}>F$ & $<.0001$ & & $<.0001$ & & 0.002 & \\
\hline
\end{tabular}

Note. Statistically significant ${ }^{* * *}$ at $99 \%$ and ${ }^{* *}$ at $95 \%$. 


\section{H3: Student perceptions of DSL benefits will be high (mean $>5$ on a 7-point scale) in the PR course}

To test H3, the means for items measuring DSL benefits were examined. As shown in Table 4, the means ranged from 5.22 to 6.28 . All items produced means above 5. The item "ability to work with others" generated the highest mean (6.28) followed by the item "presentation skills" (6.22), and "client relations" (6.19). The last three columns in Table 4 show the results of factor analysis of items measuring DSL benefits using the same methods described earlier. Even though all three composite measures produced almost the same means, the "managerial skills" measure produced the highest mean (5.88) followed by "technical skills" (5.84). Thus, the results supported H3.

Table 4. Descriptive Statistics and Principal Component Analysis for Discipline-Specific Learning (DSL) Benefits

\begin{tabular}{|c|c|c|c|c|c|c|c|}
\hline & \multirow{2}{*}{ Item } & \multirow{2}{*}{ Mean } & \multirow{2}{*}{$\begin{array}{l}\text { Std. } \\
\text { Dev. }\end{array}$} & \multirow{2}{*}{$\begin{array}{r}\text { Factor } \\
\text { Mean }\end{array}$} & \multicolumn{3}{|c|}{ Factor Loading } \\
\hline & & & & & 1 & 2 & 3 \\
\hline \multirow[t]{16}{*}{$\begin{array}{l}\text { Factor 1: Organizational } \\
\text { Skills }\end{array}$} & & & & 5.74 & & & \\
\hline & Organizational skills & 6.06 & 0.89 & & 0.833 & & \\
\hline & $\begin{array}{r}\text { Ability to work with } \\
\text { others }\end{array}$ & 6.28 & 0.78 & & 0.760 & & \\
\hline & $\begin{array}{r}\text { Strategic planning } \\
\text { skills }\end{array}$ & 5.81 & 1.01 & & 0.722 & & \\
\hline & $\begin{array}{r}\text { Quantitative research } \\
\text { skills }\end{array}$ & 5.22 & 1.68 & & 0.647 & & \\
\hline & $\begin{array}{r}\text { Qualitative research } \\
\text { skills }\end{array}$ & 5.36 & 1.46 & & 0.634 & & \\
\hline & Factor 2: Technical Skills & & & 5.84 & & & \\
\hline & Presentation skills & 6.22 & 0.99 & & & 0.798 & \\
\hline & $\begin{array}{r}\text { Technology/social } \\
\text { media skills }\end{array}$ & 5.89 & 1.55 & & & 0.731 & \\
\hline & Writing/editing skills & 5.83 & 1.08 & & & 0.676 & \\
\hline & Design skills & 5.42 & 1.50 & & & 0.664 & \\
\hline & Factor 3: Managerial Skills & & & 5.88 & & & \\
\hline & Managerial skills & 5.75 & 1.27 & & & & 0.878 \\
\hline & Creative expression & 5.58 & 1.34 & & & & 0.833 \\
\hline & Client relations & 6.19 & 1.21 & & & & 0.721 \\
\hline & Event planning & 6.00 & 1.17 & & & & 0.653 \\
\hline
\end{tabular}

Note. $\mathrm{n}=36$. All items were measured on a 7-point scale. Extraction method: Principal component analysis. Rotation method: Varimax with Kaiser normalization. Blank cells represent loadings $<0.50$. Source: Authors' survey. 


\section{H4: Student perceptions of DSL benefits predict perceived effectiveness of the PR course}

In testing H4, the regression analysis (Model 2 in Table 3) indicated that all three measures positively impacted overall course effectiveness, while the two measures - "organizational skills" and "technical skills"-were statistically significant at the $99 \%$ level. The results supported H4.

\section{RQ1: What learning benefits are the best predictors of course effectiveness?}

For RQ1, all seven composite measures were included in the regression (see the results under Model 3 in Table 3). Only one composite measure was statistically significant at the $99 \%$ level- "technical skills"which can be considered the best predictor of perceived course effectiveness. The item "technical skills" included presentation skills, technology/social media skills, writing/editing skills, and design skills. This contrasted with Werder and Strand's (2011) findings, which showed three composite factors serving as unique predictors of course effectiveness.

\section{RQ2: Are there differences in student perceptions of experiential learning outcomes due to gender or client type?}

For RQ2, independent samples t-tests were conducted for individual items for both GSL and DSL benefits to compare means of student perceptions of experiential learning outcomes by gender. The results are summarized in Table 5. Only three items revealed statistically significant differences in means: skills in learning from experience, design skills, and organizational skills, with females having higher means. Overall, there was no significant difference in means by gender in learning experience. This contrasted with Werder and Strand's (2011) finding that gender had a significant effect on perceptions of creative and practical skills gained, with females also having higher means.

Table 5. Independent Samples T-Test

\begin{tabular}{|c|c|c|c|c|c|c|}
\hline \multirow[t]{2}{*}{ Item } & \multicolumn{3}{|c|}{ Gender } & \multicolumn{3}{|c|}{$\begin{array}{r}\text { Dillsboro } \\
\text { Campaign }\end{array}$} \\
\hline & $\mathbf{M}$ & $\mathbf{F}$ & t stat & Yes & No & t stat \\
\hline \multicolumn{7}{|l|}{ General Service-Learning Experience } \\
\hline Personal growth & 5.54 & 5.73 & -0.48 & 5.88 & 5.33 & 1.52 \\
\hline Ability to work with others & 5.85 & 6.14 & -1.01 & 6.18 & 5.89 & 1.04 \\
\hline Leadership skills & 5.85 & 6.27 & -1.49 & 6.29 & 5.89 & 1.49 \\
\hline Communication skills & 6.23 & 6.18 & 0.18 & 6.29 & 6.11 & 0.71 \\
\hline Understanding cultural differences & 5.31 & 4.59 & 1.12 & 4.59 & 4.94 & -0.58 \\
\hline Social responsibility and citizenship skills & 5.62 & 4.91 & 1.26 & 5.12 & 5.17 & -0.09 \\
\hline Community involvement & 6.31 & 6.36 & -0.19 & 6.59 & 6.11 & 1.73 \\
\hline Applying knowledge to the "real world" & 5.92 & 6.05 & -0.40 & 6.18 & 5.83 & 1.17 \\
\hline Problem analysis and critical thinking & 6.08 & 5.95 & 0.40 & 6.06 & 5.89 & 0.58 \\
\hline Social self-confidence & 5.31 & 5.64 & -0.70 & 5.35 & 5.67 & -0.68 \\
\hline Conflict resolution & 5.69 & 5.82 & -0.29 & 5.94 & 5.56 & 0.93 \\
\hline Ability to assume personal responsibility & 5.67 & 6.18 & -1.13 & 6.18 & 5.82 & 0.91 \\
\hline
\end{tabular}




\begin{tabular}{|c|c|c|c|c|c|c|}
\hline \multirow[t]{2}{*}{ Item } & \multicolumn{3}{|c|}{ Gender } & \multicolumn{3}{|c|}{$\begin{array}{r}\text { Dillsboro } \\
\text { Campaign }\end{array}$} \\
\hline & $\mathbf{M}$ & $\mathbf{F}$ & t stat & Yes & No & t stat \\
\hline Development of caring relationships & 5.31 & 5.27 & 0.06 & 5.00 & 5.50 & -0.88 \\
\hline Gaining the trust of others & 5.69 & 5.59 & 0.25 & 5.47 & 5.78 & -0.79 \\
\hline Sensitivity to the plight of others & 5.54 & 5.82 & -0.63 & 5.65 & 5.72 & -0.18 \\
\hline Workplace skills & 5.69 & 5.68 & 0.03 & 5.82 & 5.50 & 1.10 \\
\hline Ability to make a difference in the community & 5.85 & 5.86 & -0.04 & 6.00 & 5.72 & 0.60 \\
\hline Skills in learning from experience & 5.62 & 6.27 & $-2.45^{* *}$ & 6.18 & 5.83 & 1.27 \\
\hline Organizational skills & 5.69 & 5.95 & -0.64 & 6.12 & 5.61 & 1.30 \\
\hline Connecting theory and practice & 6.08 & 6.00 & 0.20 & 6.24 & 5.72 & 1.40 \\
\hline \multicolumn{7}{|l|}{ Discipline-Specific Learning Experience } \\
\hline Qualitative research skills & 5.08 & 5.59 & -1.01 & 5.47 & 5.17 & 0.61 \\
\hline Quantitative research skills & 4.92 & 5.45 & -0.90 & 5.47 & 4.89 & 1.03 \\
\hline Strategic planning skills & 5.54 & 6.00 & -1.31 & 6.06 & 5.50 & 1.69 \\
\hline Writing/editing skills & 5.85 & 5.82 & 0.08 & 5.76 & 5.83 & -0.19 \\
\hline Design skills & 4.85 & 5.73 & $-1.70^{*}$ & 5.18 & 5.56 & -0.74 \\
\hline Ability to work with others & 6.00 & 6.41 & -1.53 & 6.53 & 6.00 & 2.11 \\
\hline Presentation skills & 5.92 & 6.36 & -1.28 & 6.24 & 6.17 & 0.20 \\
\hline Event planning & 6.15 & 6.00 & 0.38 & 6.24 & 5.72 & 1.30 \\
\hline Client relations & 6.38 & 6.05 & 0.79 & 6.06 & 6.28 & -0.52 \\
\hline Creative expression & 5.38 & 5.68 & -0.62 & 5.65 & 5.44 & 0.44 \\
\hline Managerial skills & 5.46 & 5.91 & -0.99 & 5.82 & 5.61 & 0.49 \\
\hline Organizational skills & 5.54 & 6.36 & $-2.87^{* * *}$ & 6.24 & 5.83 & 1.35 \\
\hline Technology/social media skills & 5.46 & 6.09 & -1.16 & 6.00 & 5.72 & 0.52 \\
\hline
\end{tabular}

Note. $\mathrm{n}=13$ for male; $\mathrm{n}=22$ for female. $\mathrm{n}=17$ for Dillsboro campaign; $\mathrm{n}=18$ for non-Dillsboro campaign. Statistically significant ${ }^{* * *}$ at $99 \%{ }^{* *}$ at $95 \%$, and $*$ at $90 \%$.

\section{RQ3: What impact does time have, if any, on the students' perceptions of volunteerism, social responsibility and citizenship?}

Due to small sample size, no statistical analysis could be conducted for each semester during which the students were enrolled. Instead, a new binary variable was created for the time period before and after 2011 in order to measure the impact of time on the students' commitment to volunteerism, social responsibility, citizenship, and so on. Independent samples t-tests were then conducted for individual items in order to compare means of those items. As shown in Table 6, two items showed a significant difference in means between the two periods: "I volunteer to show future employers my interest in the community" and "I have made career decisions based on my community engagement experience." Interestingly, students graduating after 2011 had the highest mean scores for those items. 
Table 6. Independent Samples T-Test

\begin{tabular}{|c|c|c|c|}
\hline \multirow{2}{*}{ Item } & \multicolumn{3}{|c|}{ Before 2011} \\
\hline & Yes & No & t stat \\
\hline $\begin{array}{l}\text { I believe I have a greater understanding of the problems that impact our } \\
\text { communities. }\end{array}$ & 5.62 & 5.80 & -0.49 \\
\hline I believe I can have a positive impact on issues in my community. & 6.38 & 6.35 & 0.12 \\
\hline $\begin{array}{l}\text { I believe involvement in community service will have a positive impact on } \\
\text { my quality of life. }\end{array}$ & 6.00 & 6.45 & -1.41 \\
\hline I volunteer to show future employers my interest in the community. & 5.85 & 6.50 & $-2.25^{* *}$ \\
\hline I feel a lifelong commitment to helping others. & 6.23 & 6.25 & -0.06 \\
\hline I often think about how my involvement will impact those I serve. & 6.38 & 6.35 & 0.12 \\
\hline $\begin{array}{l}\text { I have made career decisions based on my community engagement } \\
\text { experience. }\end{array}$ & 5.08 & 6.10 & $-1.94^{*}$ \\
\hline I have an increased understanding of the value of civic responsibility. & 5.85 & 6.05 & -0.54 \\
\hline Involvement in community service has influenced the way I live my life. & 5.62 & 5.75 & -0.36 \\
\hline
\end{tabular}

Note. $\mathrm{n}=13$ for Before_2011; $\mathrm{n}=20$ for After_2011. Statistically significant ${ }^{* *}$ at $95 \%$ and $*$ at $90 \%$.

\section{RQ4: Do students assigned to an official university partner (in this case, a small tourist town) report different perceptions/experiences for any of the variables?}

For RQ4, independent samples t-tests were conducted for individual items for both GSL and DSL benefits to compare means of student perceptions of experiential learning outcomes by client type (i.e., nonprofit vs. for-profit organizations). Approximately half of the students (48.6\%) were assigned to the small businesses in the tourist town, while the other half (51.4\%) worked for nonprofit organizations. As shown earlier in Table 5, three items demonstrated statistically significant differences in means: community involvement, strategic planning skills, and ability to work with others. Overall, there was no significant difference in means by client type in learning experience. Comparing these findings with those of Werder and Strand (2011), results showed no statistically significant differences (at the .05 level) in students' perceptions based on client type in relation to what Werder and Strand identified as the ServiceLearning Citizenship Skills scale, which includes the following items:

- community involvement;

- ability to make a difference in the community;

- social responsibility and citizenship skills; and,

- understanding cultural (and racial) differences.

These particular findings contrast with Werder and Strand's (2011), which found a statistically significant difference in means between students who were placed with corporations versus not-for-profit organizations. That is, students who were working with not-for-profit organizations perceived greater 
gains in citizenship skills than their peers who were placed with corporations. For this study, project type had no influence on the students' perceived development of citizenship skills acquired through their community-based projects. The students who were assigned to the small tourist town, which was designated as an official engagement partner of the university, did not report greater gains in skills related to community involvement, social responsibility, and citizenship than their peers assigned to a diverse collection of nonprofit clients. However, in this study, the alumni who had worked for the for-profit tourist town had higher mean scores on one single item in the GSL section-community involvementand one item from the DSL section - the ability to work with others.

\section{Qualitative Results}

In addition to descriptive statistics, two of the authors each worked independently to analyze and identify themes emerging from the students' responses to RQ5, RQ6, and RQ7. The authors shared their themes, found considerable overlap, and agreed on emerging themes for each question. This analysis provided further insight into students' perceptions of the role of universities in general and public relations education specifically in helping students develop as civic-minded and socially responsible members of society.

\section{RQ5: To what extent do PR students working on real-world projects in the community perceive their work as helping the university achieve its mission as an engaged university?}

The graduates in this study made a clear connection between the university's community engagement mission and their work in the PR Campaigns class. While $94 \%$ of respondents strongly agreed or agreed that their work in the class helped contribute to the university's mission to improve lives and to enhance community development, $80 \%$ perceived themselves as contributing to economic development in their community. Respondents highlighted both the role and the power of the university to fulfill this work. For example, one respondent said:

The purpose of regional universities is to assist in developing and sustaining the economies of the areas ... which they serve. This means its students should be involved in the local community through community service activities, service-learning opportunities, and even internships. Successful student engagement is key to allowing universities [to] fulfill that purpose.

\section{RQ6: Do graduates believe that universities generally and the PR Campaigns course specifically should foster future students' development in citizenship and social responsibility?}

All respondents (100\%) agreed that universities should play a role in developing students' civic mindedness. Qualitative analysis of the responses to this question resulted in the following three themes:

1. Exposure. Respondents identified the college years as an opportune time for both personal and professional development and to engage with communities. Illustrating this theme of exposure, one alumni indicated that his experience working on a literacy campaign

presented many challenges to my own perception of the world around me by exposing me to the real struggles of those less fortunate. The campaign forced me to think critically, better understand social issues (literacy being much larger than I realized) and provided hands-on experience that I don't believe I could find in a classroom.

2. Imprinting. This theme relates to the lasting impact of the university on an individual. Several respondents' comments evoked this theme, including the following: "I think universities can teach the importance of giving back that can be instilled in a student's belief for all time and it's 
something they can pass on," and connecting with community while in college will "hopefully inspire a lifetime of involvement within one's community later in life."

3. Activating the whole person. This theme was illustrated by respondents who suggested that university education represents more than simply training specialists for a particular field of study; as one graduate said, it is about developing "well-rounded persons who are able to step into the 'real world' with an understanding of their community affairs and be able to actively participate."

While all respondents agreed that it was the university's job to foster students' development in citizenship and social responsibility, $86 \%$ percent indicated that the PR Campaigns course should be designed with this in mind. Responses to this portion of RQ6 generally fell into the following four themes:

1. The development of a lifelong habit of community involvement. The idea that time spent in the PR Campaigns service-learning project had been translated into a permanent habit of volunteering is illustrated in this comment: "Working with [the tourist town] was an extremely rewarding experience for me, and I continue to volunteer because of my time helping this little town."

2. The value of PR skills in making a difference. This theme was reflected in comments such as "PR practitioners have skills that, when used properly, can help people help themselves" and "Students should learn that the tools learned in PR can be used to better their communities."

3. The transition from college to the professional world. Comments focusing on the transition from college to the professional world were especially revealing. Respondents perceived themselves as students "becoming" and "aspiring" to be adults, suggesting an awareness of the distinct growth and shift that comes with no longer being identified as a student. Regarding this shift, students recognized that their engagement with real-world organizations was essential for "facilitat[ing] the transition from college-based social life to a real-world social life." Another student shared that he felt more prepared for the professional world because the PR Campaigns course "helped [him] appreciate that value of hard work."

4. Beyond altruism toward a recognition of instrumental value. Perhaps the most intriguing theme that emerged from students' responses about whether the PR Campaigns course should be designed to foster students' development in citizenship and social responsibility revolved around their recognition of the instrumental value of such an approach. Many respondents emphasized that their understanding of and commitment to social responsibility and the community could also benefit them professionally. Beyond altruistic reasons for "doing good," several respondents cited the growing opportunity for employment at companies that espouse social responsibility as part of their brand. As one respondent commented: "More companies like TOMS, BANGS, etc., see the benefit of branding themselves as socially responsible companies. Understanding the importance of being socially responsible will open more doors for companies like these." Another said, "Those aspects are reflected in the real world. Real companies invest in social responsibility, and it's important for students and candidates for work to show they've been involved, have made a difference and really care about something. It's important for us to give back."

\section{RQ7: Do graduates retain comprehension of the significance that $P R$ practitioners play in the life of a community and their social responsibility toward that community?}

As a result of their work in the PR Campaigns class, graduates of the program under study reported that they learned about many aspects of citizenship and social responsibility. Three broad themes emerged: 
1. The reciprocal nature of giving. Students reported overwhelmingly that they gained as much as they gave and that they gained in areas beyond the development of professional skills. As one respondent said: "I got a lot in return by giving back to the community."

2. The satisfying realization that students could make a difference. Respondents made significant gains in their sense of empowerment or self-efficacy (e.g. "If you don't take initiative, who will?"). They reported feeling that they could use their PR skills to affect change (e.g., "I learned that if I have the skills and abilities to give back to those around me, why not do it?") Emphasizing how satisfying this realization was, another respondent said, "I went to bed knowing I made a difference, and who doesn't like that?"

3. A genuine sense of caring. Students reported developing a genuine concern for the clients/communities they were working with both while as students and, later, as alumni/professionals. As one said: "Being linked with the merchants of [the tourist town] for an entire semester helped build relationships where it didn't necessarily feel like an obligation or just another class project. It became very real and we began to genuinely care about the success of the community and our campaign." Citing the fact that her boss had made it very apparent how important it was to give back to the community, another respondent who worked at a large corporation concluded: "We have a responsibility to our community to help it grow and succeed."

\section{Discussion}

The study findings have implications for universities, public relations education, the public relations profession, and the fields of service-learning and community engagement. Overall, the results support the use of Werder and Strand's (2011) general service-learning instrument to assess expected and desired learning outcomes in the PR Campaigns course. In addition, the study makes an important contribution to the literature by extending the assessment process to include alumni. If scholars and practitioners are to fully understand and document the value of service-learning as a model pedagogy in the PR Campaigns class and as a model for developing socially responsible professionals across disciplines, such an extension is necessary.

While the four hypotheses of this study were strongly supported by statistical testing, some results contrasted with Werder and Strand's (2011) findings. For example, while three items were statistically different (skills in learning from experience, design skills, and organizational skills), with females having higher means, the overall GSL and DSL scores demonstrated no statistically significant differences based on gender. Additionally, overall there were no statistically significant differences in means by client type (profit vs. nonprofit) in relation to learning experience. This contrasted with Werder and Strand's findings, illuminating potentially key factors associated with the types of partnerships that can lead to valuable service-learning outcomes. The fact that the vast majority of the for-profit businesses students worked with in this study were associated with the university's engagement focus, and mostly consisted of struggling for-profits, could have impacted these results. However, there were differences in the two groups (profit vs. nonprofits) on single items. The alumni who had worked for the tourist town had higher mean scores on one single item on the GSL section (i.e., community involvement) and one item from the DSL (i.e. the ability to work with others). It is quite possible that the students working with the tourist town scored higher on these two items because of the unique relationship this five-year university engagement partnership created. As one of the members of the town said in characterizing the partnership, "It created a new mindset. We pulled together with the university. It pulled us together." The town, faculty, and students had worked extremely closely for many years, and the nature of this partnership may have influenced students' responses. However, due to the small sample size of this study, additional research is needed in order to document statistically significant findings.

Both the quantitative and qualitative results suggest that, for graduates of the program being studied, the goals of service-learning - which go well beyond PR skills development to include citizenship and social responsibility — were realized and, most importantly, "stuck" post-graduation. Such assessment of 
alumni is critical not just for PR programs, but for universities documenting the impact of their engagement activities on students' lifelong learning and commitment to social responsibility. Surveys of alumni are difficult to conduct, but the findings from this study demonstrate the value of that effort.

\section{Implications and Recommendations}

The study findings have important implications for faculty utilizing service-learning in the PR Campaigns course. We concur with Allison's (2008) suggestion that one of the learning objectives in the PR Campaigns course should be "to enhance personal citizenship through service and civic participation" and that one of the teaching objectives should be "to promote the reciprocal merits of service-learning among students, community, and college/university partners" (p. 52). Such specific articulation of these outcomes would help students immediately place their PR work within a larger context. As one graduate in this study stated:

By supporting development in citizenship and social responsibility, PR Campaigns can have that impact on others after college. The PR industry is well known for its "spin" on the truth. Creating a new generation of socially responsible PR workers can shape our industry into a better one.

Public relations practitioners and educators often do not take advantage of opportunities to collaborate. However, PR practitioners responsible for promoting engaged universities and PR faculty using servicelearning in the capstone course should work together to publicize the impact of those projects in their community. Such publicity could help improve the image of the university in the eyes of the community, increase the stature of the university's PR program, and generally contribute to an improved image of the practice of public relations.

Finally, graduates in this study cited career readiness as an important outcome of their servicelearning experience and identified community-engaged learning as a core contributor of that shift. These findings suggest that community-engaged learning may help ameliorate the transition into new careers by directly preparing students for them. Indeed, this study highlights the promise of service-learning, community engagement, and PR education as powerful partners with benefits for universities, graduates, communities, and the PR profession.

\section{Author Note}

Betty Farmer, Communication Department, Western Carolina University; Lane Graves Perry, III, Center for Service Learning, Western Carolina University; Inhyuck "Steve" Ha, School of Economics, Management, and Project Management, Western Carolina University.

\section{Correspondence}

Correspondence regarding this article should be addressed to Betty Farmer, Professor of Communication and Public Relations, Western Carolina University, 233 Stillwell, 1 University Drive, Cullowhee, NC 28723. Phone: (828) 227-3804. E-mail: bfarmer@email.wcu.edu

\section{References}

Aldoory, L., \& Wrigley, B. (2000). Exploring the use of real clients in the PR Campaigns course. Journalism and Mass Communication Educator, 54(4), 47-48. 
Allison, A. (2008). A best practices service-learning framework for the Public Relations Campaigns course. Journal of the Scholarship of Teaching and Learning, 8(3), 50-60.

Astin, A. W., Sax, L. J., \& Avalos, J. (1999). Long-term effects of volunteerism during the undergraduate years. Review of Higher Education, 22(2), 187-201.

Astin, A. W., Vogelgesang, L. J., Ikeda, E. K., \& Yee, J. A. (2000). How service-learning affects students. Los Angeles: Higher Education Research Institute, UCLA.

Blomstrom, S., \& Tam, H. (2008). Service-learning projects using outcome measures recommended by the commission on public relations education. In M. Bowden, S. Billig, \& B. Holland (Eds.), Scholarship for sustaining service-learning and civic engagement (pp. 139-160). Charlotte, NC: Information Age Publishing.

Buys, N., \& Bursnall, S. (2007). Establishing university-community partnerships: Processes and benefits. Journal of Higher Education Policy and Management, 29(1), 73-86.

Campus Compact. (2013). Indicators of engagement revised for minority-serving institutions. Retrieved from http://www.compact.org/resources/service-learning-resources/indicators-of-engagementproject/indicators-of-engagement-revised-for-minority-serving-institutions/3525/

Carnegie Foundation for the Advancement of Teaching. (2013). Classification description. Retrieved from http://classifications.carnegiefoundation.org/descriptions/ community engagement.php

Celio, C., Durlak, J., \& Dymnicki, A. (2011). A meta-analysis of the impact of service-learning on students. Journal of Experiential Learning, 34(2), 164-181.

Clayton, P., Ash, S., Bullard, L., Bullock, B., Moses, M., Moore, A., O’Steen, W., Stallings, S., \& Usry, R. (2005). Adapting a core service-learning model for wide-ranging implementation: An institutional case study. Creative College Teaching Journal, 2(1), 10-27.

Cruz, N., \& Giles, D. (2000). Where's the community in service-learning research? Michigan Journal of Community Service-Learning, (Special Issue), 28-34.

Daugherty, E. (2003). Service-learning integration in a public relations program pedagogy for enhanced learning. Teaching Public Relations, 58, 1-9.

Driscoll, A. (2008). Carnegie's Community Engagement Classification: Intentions and insights. Change, January/February, 39-41

Driscoll, A., Holland, B., Gelmon, S., \& Kerrigan, S. (1996). An assessment model for service-learning: Comprehensive case studies of impact on faculty, students, community, and institution. Michigan Journal of Community Service-Learning, 3, 66-71.

Eyler, J., \& Giles, D. (1999). Where's the learning in service-learning? San Francisco, CA: Jossey Bass.

Eyler, J., Giles, D., Stenson, C., \& Gray, C. (2001). At a glance: What we know about the effects of service-learning on college students, faculty, institutions, and communities, 1993-2000 (3 ${ }^{\text {rd }} \mathrm{ed}$.). Nashville, TN: Vanderbilt University.

Farmer, B. (1997). Using SPE context analysis in the Public Relations Campaigns class. Teaching Public Relations, 44, 1-6.

Fenzel, M., \& Peyrot, M. (2005). Comparing college community participation and future service behaviors and attitudes. Michigan Journal of Community and Service-Learning, 12(1), 23-31.

Gelmon, S., Holland, B., Driscoll, A., Spring, A., \& Kerrigan, S. (2001). Assessing service-learning and civic engagement: Principles and techniques. Providence, RI: Campus Compact.

Gleason, J., \& Violette J. (2012) Integrating service-learning into public relations coursework: Applications, implications, challenges, and rewards. International Journal of Teaching and Learning in Higher Education, 24(2), 280-285.

Gray, M, Ondaatje, E., Fricker, R., \& Geschwind, S. (2000). Assessing service-learning: The benefits of service-learning for students. Change, 3(2), 30-41.

Holland. B. (1997). Analyzing institutional commitment to service: A model of key organizational factors. Michigan Journal of Community Service-Learning, Fall, 30-41.

Holland, B. (2001). A comprehensive model for assessing service-learning and community-university partnerships. New Directions for Higher Education, 114, 51-60. 
Holsti, O.R. (1969). Content analysis for the social sciences and humanities. Reading, MA: AddisonWesley.

Johnson, S. D., \& Bozeman, M. (1998). Service-learning and the development of social responsibility. Paper presented at the Annual Convention of the Central States Communication Association, Chicago, IL.

Kinnick, K. N. (1999). The communication campaigns course as a model for incorporating servicelearning into the curriculum. In D. Droge \& B. Orega Murphy (Eds.), Voices of strong democracy concepts and models for service-learning in communication studies (pp. 155-164). Washington, DC: American Association of Higher Education.

Lincoln, Y. S., \& Guba, E. G. (1985). Naturalistic inquiry. Beverly Hills, CA: Sage Publications.

Markus, G. B., Howard, J. P. F., \& King, D. C. (1993). Integrating community service and classroom instruction enhances learning: Results from an experiment. Educational Evaluation and Policy Analysis, 15(4), 410-419.

Payne, C. A. (2000). Changes in involvement preferences as measured by the Community Service Involvement Preference Inventory. Michigan Journal of Community Service Learning, 7, (1) .

Sallot, L. M. (1996). Using a public relations course to build university relationships. Journal of Mass Communication Education, Spring, 51-60.

Slater, J. R., Bartoo, C. W., \& Puglisi, G. (2011). Desirable characteristics of campaigns course pedagogy: Are accepted practices the best practices? Proceedings of the Public Relations Society of America Educators Academy, Orlando, FL.

Smedick, W. D. (1996). A study of the effect of a volunteer service program at an urban-based institution of higher education on the current level of service achieved by alumni who had participated in the program (Unpublished doctoral dissertation). Morgan State University, Baltimore, MD.

Souza, T. (1999). Service-learning and interpersonal communication: Connecting students with the community. In D. Droge \& B. Ortega Murphy (Eds.), Voices of strong democracy: Concepts and models for service-learning in communication studies (pp. 77-87). Sterling, VA: Stylus.

Stanton, T. (2009). Community engagement and critical analysis: Essential elements for character building education in the United States and South Africa. In G. Chuan, V. D’Rozario, A. Heong, \& C. Mun (Eds.), Character development through service and experiential learning. Singapore: Prentice Hall.

Texter, L., \& Smith, M. (1999). Public relations and public service: Integrating service-learning into the public relations seminar. In D. Droge \& B. Murphy (Eds.), Voices of strong democracy: Concepts and models for service-learning in communication studies (pp. 165-175). Sterling, VA: Stylus.

Toncar, M., Reid, J., Burns, D., Anderson, C., \& Nguyen, H. (2006). Uniform assessment of the benefits of service-learning: The development, evaluation, and implementation of the SELEB scale. Journal of Marketing Theory and Practice, 14(3), 223-238.

Weber, J., \& Weber, P. (2010). Service-learning: An empirical analysis of the impact of service-learning on civic mindedness. Journal of Business, Society and Government, Spring, 79-94.

Werder, K. P., \& Strand, K. (2011). Measuring student outcomes: An assessment of service-learning in the Public Relations Campaigns course. Public Relations Review, 37, 478-484.

Witmer, D. F., Silverman, D. A., \& Gashcen, D. J. (2009). Working to learn and learning to work: A profile of service-learning courses in university public relations programs. Public Relations Review, $35(2), 153-155$. 